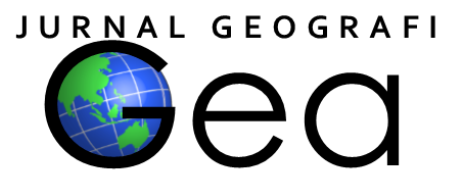

\title{
PERUBAHAN ORIENTASI PRODUKSI ALAT TENUN BUKAN MESIN (ATBM) DARI TENUN KAIN MENJADI TENUN KESET (UPAYA PENINGKATAN PENDAPATAN PENGRAJIN DI KECAMATAN IBUN KABUPATEN BANDUNG)
}

\author{
Neneng Sri Andini ${ }^{1}$, Rinayanti Laila Nurwulan ${ }^{2}$, Upi Supriatna ${ }^{3}$ \\ ${ }^{123}$ Program Studi Pendidikan Geografi, Fakultas Keguruan Dan Ilmu Pendidikan, \\ Universitas Bale Bandung \\ ${ }^{1}$ nenengsriandini925@gmail.com, ${ }^{2}$ rina.ellen205199@gmail.com, ${ }^{3}$ upisupriatna80@ gmail.com
}

\begin{abstract}
The 1930s were the beginning of the development of the textile industry in Majalaya and its surroundings, namely the home weaving industry that uses non-machine loom (ATBM). began to be displaced because they were unable to compete with machine looms (ATM). This does not necessarily make the Majalaya community and their surroundings innovate with a non-machine loom hich was originally used to weave cloth now into woven mats. This study aims to determine the development of the ATBM industry after the existence of ATM, the existence of the ATBM woven fabric industry after the rise of ATM, as well as the effect of ATBM production from woven cloth to woven mats to increase craftsman income. This research uses quantitative descriptive method by conducting field observations, interviews, questionnaires, documentation studies, literature reviewers. The location used as the population is Ibun Village because at the moment Ibun Village is famous as a mat producing area with a total sample of 66 respondents using the $R A O$ formula. The results showed the existence of the traditional weaving industry still survives to this day although the production produced is no longer woven cloth but weaving doormat (100\%), the existence of the woven fabric industry with ATBM is still there it's just that it is very rare because it has been carried out innovations that were previously the ATBM producing woven cloth now produces woven mat (29\%), changes in production orientation have a significant influence on the economic life of the local population (100\%).
\end{abstract}

Keywords: Industry, Ibun, ATBM, Doormats

\begin{abstract}
ABSTRAK
Tahun 1930-an merupakan awal perkembangan industri tekstil di Majalaya dan sekitarnya, yaitu industri tenun rumahan yang menggunakan alat tenun bukan mesin (ATBM). mulai tergeser karena tidak mampu bersaing dengan alat tenun mesin (ATM). Hal ini tidak serta merta membuat masyarakat Majalaya dan sekitarnya mereka berinovasi dengan alat tenun bukan mesin (ATBM) yang semula dimanfaatkan menenun kain sekarang menjadi tenun keset. Penelitian ini bertujuan untuk mengetahui perkembangan industri ATBM setelah adanya ATM, eksistensi industri tenun kain ATBM setelah maraknya ATM, serta pengaruh produksi ATBM dari tenun kain menjadi tenun keset terhadap peningkatan pendapatan pengrajin. Penelitian ini menggunakan metode deskriftif kuantitatif dengan melakukan observasi lapangan, wawancara, angket, studi dokumentasi, penelaah pustaka. Lokasi yang dijadikan populasi dalam penelitian adalah Desa Ibun karena pada saat ini Desa Ibun terkenal sebagai wilayah penghasil keset dengan jumlah sampel sebanyak 66 responden dengan menggunakan rumus RAO. Hasil
\end{abstract}


penelitian menunjukan keberadaan industri tenun tradisional masih bertahan hingga saat ini meskipun produksi yang di hasilkan bukan lagi tenun kain tetapi tenun keset (100\%), eksistensi industri tenun kain dengan ATBM masih ada hanya saja sudah sangat jarang karena sudah dilakukan inovasi yang tadinya ATBM tersebut menghasilkan tenun kain sekarang menghasilkan tenun keset (29\%), perubahan orientasi produksi memberikan pengaruh yang signifikan terhadap kehidupan ekonomi penduduk setempat (100\%).

Kata kunci: Industri, Ibun, ATBM, Keset

\section{PENDAHULUAN}

Tahun 1930-an merupakan awal perkembangan industri tekstil Majalaya yang dipelopori oleh beberapa pengusaha tekstil lokal seperti Ondjo Argadinata. Masa-masa tersebut diwarnai dengan bermunculannya industri tenun rumahan yang menggunakan alat tenun bukan mesin (ATBM) sebagai alat produksinya. Penyebaran kegiatan menenun berlangsung cukup merata karena; (1) tingginya persentase rumah tangga yang tidak memiliki lahan dan melakukan pertanian marginal, (2) kegiatan menenun merupakan tradisi lama, namun masih menjadi tipikal keterampilan perempuan kelas menengah (Hardjono, 1990 dan Pleyte, 1912 dalam Keppy, 2001). Selain itu, keterlibatan buruhburuh di pabrik-pabrik tenun pada awal tahun 1930-an memberi bekal mereka untuk membuka usaha tenun sendiri, saat pasar semakin terbuka mereka mudah mengambil kesempatan tersebut karena modal yang diperlukan untuk membeli alat tenun masih murah dan bahan baku bisa diperoleh dari para pengusaha.

Masa berikutnya industri tenun rumahan semakin menjamur di mana-mana. Hampir setiap penduduk Majalaya memiliki peralatan tenun dan membuka usaha tenun sendiri, oleh penduduk yang telah berusia lanjut masa tersebut dikenang sebagai masamasa keemasan Majalaya. Namun, hal ini merupakan kemajuan secara umum karena jika ditelusuri pada saat yang sama para pengusaha tenun lokal sudah mulai kehilangan pengaruhnya untuk mempertahankan kelangsungan produksi. Banyak perusahaan lokal yang beralih ke sistem maklun, berdasarkan data yang diperoleh dari IKM TPT Majalaya dapat diakumulasikan sebagai berikut.

Tabel 1. Data Perusahaan Industri Kecil Menengah Pertenunan Majalaya dan Sekitarnya di Kabupaten Bandung tahun 2011-2015

\begin{tabular}{cccccc}
\hline Tahun & 2011 & 2012 & 2013 & 2014 & 2015 \\
\hline Jumlah perusahaan & 129 & 186 & 180 & 173 & 170 \\
\hline
\end{tabular}

Industri tenun rumahan juga mulai tergeser karena tidak mampu bersaing dengan produk yang dihasilkan oleh Alat Tenun Mesin (ATM). Sejak tahun 1970-an banyak pabrikpabrik pribumi yang dijual terhadap pengusaha asing atau WNI nonpribumi, berdirilah salah satu pabrik Cina pertama yaitu pabrik "Bintang Tujuh". Penjualan pabrik ini merupakan titik akhir dari rangkaian proses pengambilalihan perusahaan pribumi oleh pengusaha asing atau WNI non pribumi. Penurunan masa kejayaan ini seiring dengan perkembangan industri tenun yang semakin terpuruk, karena adanya krisis perekonomian yang menyebabkan banyaknya industri tenun mengalami kemunduran. Akan tetapi, hal ini tidak membuat masyarakat Majalaya berhenti untuk
Sumber: data yang diperoleh dari IKM TPT Majalaya mendirikan usahanya, mereka mencoba berinovasi dengan alat tenun bukan mesin (ATBM) yang tadinya alat tersebut menghasilkan tenun kain sekarang menghasilkan tenun keset.

Berbicara tentang sejarah perindustrian tidak akan terlepas dari Majalaya, karena wilayah Majalaya terlalu luas dilakukanlah pemekaran mejadi empat Kecamatan yaitu Kecamatan Paseh, Kecamatan Ibun, Kecamatan Majalaya dan Kecamatan Solokan Jeruk. Kecamatan Ibun menjadi salah satu contoh bagaimana masyarakat tidak berhenti untuk mendirikan usahanya dengan mempertahakan alat tenun bukan mesin (ATBM) sebagai alat produksinya, meskipun sekarang yang 
dihasikan oleh alat tersebut adalah tenun keset. Berdasarkan latar belakang masalah yang telah diuraikan di atas, penulis merumuskan masalah penelitian sebagai berikut: 1) Bagaimana perkembangan alat tenun bukan mesin (ATBM) setelah digantikan oleh alat tenun mesin (ATM) di Kecamatan Ibun, 2) Bagaimana eksistensi industri tenun kain dengan alat tenun bukan mesin (ATBM) setelah maraknya pemakaian alat tenun mesin (ATM) di Kecamatan Ibun, 3) Apakah terdapat pengaruh perubahan orientasi produksi alat tenun bukan mesin (ATBM) dari tenun kain menjadi tenun keset terhadap peningkatan penghasilan pengrajin di Kecamatan Ibun.

\section{METODE PENELITIAN}

Penelitian ini menggunakan metode penelitian deskriptif kualitatif. Metode penelitian deskriptif kuantitatif yaitu suatu metode yang digunakan dalam menganalisis data untuk menghasilkan suatu kesimpulan akhir dalam memecahkan suatu masalah. Seperti diungkapkan oleh Surakhmad (1980: 139) bahwa: "Metode deskriptif adalah metode yang mendeskripsikan atau melukiskan dan menganalisis hasil penelitian dari masalah yang ada pada masa sekarang ini”. Sedangkan menurut Sukmaatmadja (1988: 115) metode kuantitatif yakni mengolah dan menginterpretasikan data yang berbentuk angka dan perhitungan yang besifat tematik, dikenal juga sebagai metode analisis statistik. Penggunaan metode deskriptif kuantitatif ini dimaksudkan untuk menggambarkan secara tepat kondisi faktual mengenai daerah penelitian dalam memaparkan potensi dan kemungkinan pengembangannya di waktu yang akan datang.

\section{Populasi}

Populasi merupakan kelompok besar dan wilayah yang menjadi lingkup penelitian kita, Sukmadinata (2012: 250). Sementara menurut Pabundu Tika (2005: 24) populasi adalah himpunan individu atau objek yang banyaknya terbatas atau tidak terbatas, dengan demikian populasi orang sebagai populasi sasaran ditentukan sebagai berikut: Usaha industri alat tenun bukan mesin (ATBM) di Kecamata Ibun Kabupaten Bandung (pemilik usaha); dan Pengrajin alat tenun bukan mesin (ATBM) di Kecamatan Ibun Kabupaten Bandung (pegawai).

Tabel 2. Data Pengrajin ATBM di Desa Ibun Kecamatan Ibun

\begin{tabular}{|c|c|c|c|c|}
\hline No. & RW & Nama desa & Usaha ATBM & Pengrajin ATBM \\
\hline 1 & 1 & Sukaeurih & 10 & 30 \\
\hline 2 & 2 & Cikaro & 0 & 0 \\
\hline 3 & 3 & Paseh & 18 & 54 \\
\hline 4 & 4 & Batusirap & 0 & 0 \\
\hline 5 & 5 & Sindiung & 4 & 12 \\
\hline 6 & 6 & Enggok & 8 & 24 \\
\hline 7 & 7 & Patrol & 2 & 6 \\
\hline 8 & 8 & Pasirbangbara & 0 & 0 \\
\hline 9 & 9 & Pasanggrahan & 3 & 9 \\
\hline 10 & 10 & Pasirtengah & 0 & 0 \\
\hline 11 & 11 & Awilarangan & 0 & 0 \\
\hline 12 & 12 & Benteng & 5 & 15 \\
\hline \multicolumn{3}{|c|}{ Jumlah } & 50 & 150 \\
\hline
\end{tabular}

\section{Sampel}

Mempertimbangkan banyaknya pengrajin alat tenun bukan mesin (ATBM) di Kecamatan Ibun yang tersebar di 12 Desa dan luasnya populasi areal sedangkan waktu untuk pengumpulan data terbatas, penulis mengambil sampel areal dan sampel orang berdasarkan acuan; sampel merupakan bagian dari populasi yang ingin diteliti, dipandang sebagai suatu pendugaan terhadap populasi, namun bukan populasi itu sendiri. Komariah dan Satori (2012: 46) menyatakan bahwa sampel adalah bagian kecil dari anggota populasi yang diambil menurut prosedur tertentu hingga dapat mewakili populasinya secara refresentatif. Berdasarkan patokan di 
atas, penulis menentukan Desa Ibun sebagai sampel areal karena Desa Ibun merupakan wilayah penghasil keset. Adapun persebaran responden dapat dilihat pada tabel 2 .

Dari jumlah subjek di atas, menunjuk pentingnya penggunaan Teknik penentuan sampel penelitian, seperti yang dikemukakan oleh Arikunto (1997: 112) apabila jumlah sampel kurang dari 100 maka keseluruhan subjek penelitian merupakan sampel penelitian akan tetapi apabila subjek penelitian lebih dari 100 dapat ditentukan antara $10 \%-15 \%$ atau $20 \%-25 \%$.

Sampel Wilayah

Sampel wilayah dalam penelitian ini menggunakan rumus RAO (Indri 2014: 29) dengan langkah-langkah sebagai berikut:

$$
\mathrm{n}=\mathrm{N} /\left(1+\mathrm{N} \cdot \mathrm{Moe}^{2}\right)
$$

Keterangan:

$\mathrm{n}=$ jumlah sampel

$\mathrm{N}=$ jumlah populasi

Moe $=$ margin of error maksimum $(0,5)$

$\mathrm{n}=12 / 1+12 .(0,5)^{2}$

$=12 /(1+12.0,25)$

$=12 /(1+3)$

$=12 / 4$

=3 (Sampel wilayah dalam penelitian ini terdiri dari 3 wilayah yaitu Sukaeurih, Sindiung, Enggok)

Sampel Manusia

RW 1 Sukaeurih = 30 sampel

RW 5 Sindiung $=12$ sampel

RW 6 Enggok $=24$ sampel

Jumlah sampel kurang dari 100 maka keseluruhan jumlah tenaga kerja dari 3 wilayah merupakan sampel penelitian.

Tabel 3. Sampel Wilayah dan Responden Penelitian

\begin{tabular}{cccc}
\hline Desa & Nama RW & Jumlah Pegawai & Jumlah Responden \\
\multirow{3}{*}{ Desa Ibun } & Sukaeurih & 30 & 30 \\
& Sindiung & 12 & 12 \\
& Enggok & 24 & 24 \\
\hline \multicolumn{2}{c}{ Total } & $\mathbf{6 6}$ & $\mathbf{6 6}$ \\
\hline
\end{tabular}

\section{HASIL DAN PEMBAHASAN Kondisi Geografis Daerah penelitian Luas dan Letak Kecamatan Ibun}

Pemilihan Kecamatan Ibun yang dipilih oleh peneliti adalah wilayah Daerah Pilihan V (DAPIL) yang terdiri dari Kecamatan Majalaya, Kecamatan Solokanjeruk, Kecamatan Ibun dan Kecamatan Paseh. Namun wilayah yang peneliti pilih sebagai lokasi penelitian adalah Kecamatan Ibun pemilihan wilayah ini dengan alasan pada saat ini Kecamatan Ibun lebih terkenal sebagai wilayah penghasil keset.

Kecamatan Ibun memiliki letak astronomis antara $7^{0} 03^{\prime} 04,75^{\prime}$ ' LS - $7^{0} 09^{\prime}$ $32,67^{\prime \prime}$ LS dan $107^{0} 44^{\prime} 59,41^{\prime \prime}-107^{0} 48^{\prime}$ 42,33" dengan luas wilayah 6.630.237 ha. Secata administratif Kecamatan Ibun memiliki batas sebagai berikut.

Sebelah Utara : Kecamatan Majalaya

Sebelah Timur : Kecamatan Paseh

Sebelah Selatan : Kecamatan Samarang

Kabupaten Garut

Sebelah Barat : Kecamatan Pacet

Kecamatan Ibun memiliki 12 Desa, yaitu; Desa Cibeet, Desa Dukuh, Desa Ibun, Desa Karya laksana, Desa Laksana, Desa
Lampegan, Desa Mekarwangi, Desa Neglasari, Desa Pangguh Desa Sudi, Desa Talun, dan Desa Tanggulun. Terdiri dari 42 Dusun, 144 rukun warga (RW), dan 374 rukun tetangga (RT). Jarak orbitasi ke pusat pemerintahan; $48 \mathrm{Km}$ dari kantor kecamatan ke Ibukota Kabupaten dan $45 \mathrm{Km}$ ke Ibukota Provinsi yang bisa ditempuh dengan waktu \pm 2 jam dengan angkutan umum atau $\pm 1,5$ jam dengan mobil pribadi atau roda dua.

Keadaan Iklim

Kecamatan Ibun beriklim tropis dengan curah hujan rata-rata antara $1.070 \mathrm{~mm}$ per tahun. Memiliki 6 bulan basah, 1 bulan lembab dan 5 bulan kering.

Geologi dan Morfologi

Kecamatan Ibun termasuk ke dalam zona Bandung yang didominasi jenis batuan vulkanik hasil letusan Gunung Kamojang, usia batuan berkisar zaman kuarter awal, sedangkan sebaran morfologi Kecamatan Ibun datar sampai berombak $(3,9 \%)$, berombak sampai berbukit $(10,5 \%)$ dan berbukit sampai bergunung $(85,6 \%)$.

Hidrologi

Kecamatan Ibun memiliki potensi hidrologi berupa sumber daya air yang cukup 
melimpah, baik air bawah tanah maupun air permukaan. Air permukaan terdiri dari 3 danau alam serta 5 buah sungai.

Keadaan Tanah dan Penggunaan Lahan

Jenis tanah yang ada di Kecamatan

Ibun; di bagian selatan merupakan endapan tanah dari sisa-sisa pelapukan tufa vulkanis yang membentuk jenis tanah latosol tipe tropic humults dengan warna tanah kuning dan hitam.

\section{Kondisi Sosial Daerah Penelitian}

Jumlah dan Kepadatan Penduduk jumlah penduduk berdasarkan Monografi Kecamatan Ibun tahun 2018 sebanyak 83.903 jiwa yang terbagi ke dalam 26.676 kepala keluarga (KK), dengan luas wilayah 6.630,237 atau $66,30237 \mathrm{~km}^{2}$, untuk kepadatan penduduk dihitung sebagai berikut.

Kepadatan Penduduk = Jumlah Penduduk (orang)/Luas wilayah $\left(\mathrm{km}^{2}\right)$

Kepadatan Penduduk $=83.903 / 66,30235$

Kepadatan penduduk $=1.265,46 \approx 1.265$ orang $/ \mathrm{km}^{2}$

Dalam bagian ini, setelah penulis berhasil mengumpulkan berbagai data yang yang diperlukan untuk penelitian ini, maka penulis mencoba mengolah data dan menganalisisnya untuk menjawab Rumusan Masalah yang telah diajukan. Penulis akan mencoba menganalisis hasil penelitian di Kecamatan Ibun dengan menggunakan rumus presentase hasil dari penelitian dilapangan dengan mendapatkan hasil data-data observasi, tanya jawab dan penyebaran angket (kuesioner) terhadap pengrajin tenun keset, adapaun analisisnya adalah sebagai berikut:

\section{Perkembangan Alat Tenun Bukan Mesin (ATBM) Setelah Digantikan oleh Alat Tenun Mesin (ATM) di Kecamatan Ibun}

Menurut pemaparan narasumber yang saya wawancarai perkembangan alat tenun bukan mesin dari tahun ke tahun pada saat ini di Kecamatan Ibun semakin berkurang, hanya saja para pengusaha tidak langsung menutup usahanya atau gulung tikar tetapi mereka melakukan sebuah inovasi dengan merubah hasil produksi dari yang tadinya alat tenun bukan mesin (ATBM) tersebut menghasilkan tenun kain serang menghasilkan tenun keset. Dengan adanya berbagai industri tekstil di Kecamatan Ibun yang mengalami peningkatan dengan pesat, ini lah alasan yang mendorong timbulnya industri rumahan keset di Kecamatan Ibun yaitu karena banyaknya limbah kain dari industri tekstil tersebut yang merupakan bahan baku utama pembuatan keset. Jadi dapat di simpulkan bahwa pada saat ini perkembangan alat tenun bukan mesin di Kecamatan Ibun pada saat ini masih ada atau masih bisa bertahan hanya saja hasil produksinya tidak sama seperti dahulu yang menghasilkan tenun kain tetapi sekarang lebih dikenal untuk menghasilkan tenun keset. Hal ini dapat dilihat pada tabel dibawah ini.

Tabel 4. Pendapat Responden Berdasarkan Inovasi yang Dilakukan untuk Tetap Mempertahankan ATBM

\begin{tabular}{llll}
\hline No. & Option & F & \% \\
\hline 1. & Tetap menenun kain tenun dengan kualitas yang bagus & - & - \\
2. & Menenun yang menghasilkan keset & 66 & 100 \\
\hline & Jumlah & $\mathbf{6 6}$ & $\mathbf{1 0 0}$ \\
\hline
\end{tabular}

Sumber: Hasil Penelitian Penulis Tahun 2019

Tabel 4 menguatakan inovasi alat tenun bukan mesin (ATBM) agar tetap bisa berkiprah setelah sebelumnya berhenti dibidang pertenunan, sekarang mulai dilirik kembali setelah ditemukannya inovasi mengubah tenun kain menjadi tenun keset responden menjawab seluruhnya (100\%), yang memanfaatkan limbah industri sebagaimana keterangan dari responden.

2. Eksistensi Tenun Kain dengan Alat Tenun Bukan Mesin (ATBM) Setelah Maraknya Pemakain Alat Tenun Mesin (ATM) di Kecamatan Ibun 
Keberadaan indusri tenun kain dengan alat tenun bukan mesin (ATBM) di Kecamatan Ibun bisa dikatakan hampir tidak ada ini dikarenakan maraknya pemakaian alat tenun mesin (ATM) dengan alasan hasil produksi kalah bersaing dalam segi jumlah, kualitas, proses produksi lebih cepat, dan dalam menyerap tenaga kerja lebih sedikit sehingga menguntungkan untuk pengusaha karena meminimalisir pengeluaran dalam hal menggaji pegawai. Hal ini dapat dilihat pada tabel 5 dibawah ini.

Tabel 5. Pendapat Responden Berdasarkan Alasan Beralih Produksi dari Tenun Kain Menjadi Tenun Keset

\begin{tabular}{cccc}
\hline No. & Option & F & $\mathbf{\%}$ \\
\hline 1. & Mempertahankan penghasilan keluarga & 13 & 19 \\
2. & Mempertahankan ATBM yang sudah ada & 19 & 29 \\
3. & Kalah bersaing dengan ATM & 34 & 52 \\
\hline \multicolumn{2}{c}{ Jumlah } & $\mathbf{6 6}$ & $\mathbf{1 0 0}$ \\
\hline & Sumber: Hasil Penelitian Penulis Tahun & 2019
\end{tabular}

Berdasarkan tabel di atas pengrajin yang beralih produksi dari tenun kain menjadi tenun keset sebagian kecil (19\%) menyatakan mempertahankan penghasilan keluarga dikarenakan sulitnya mencari pekerjaan lain serta keahlian yang terbatas dan juga lapangan pekerjaan yang minim, hampir setengahnya (29\%) responden menyatakan alasannya dengan mempertahankan alat tenun bukan mesin (ATBM) karena apabila tidak dioperasikan alat tenun bukan mesin tersebut akan rusak termakan waktu, dan sebagian besar $(52 \%)$ alat benun bukan mesin (ATBM) kalah tersaingi oleh alat tenun mesin (ATM) dikarenakan dengan kelebihan-lekebihan teknologi yang dimiliki oleh alat tenun mesin (ATM). Tabel diatas menunjukan bahwa eksistensi industri tenun kain dengan alat tenun bukan mesin (ATBM) setelah maraknya alat tenun mesin (ATM) di Kecamatan Ibun pada saat ini hampir sudah tidak ada ini di sebabkan karena alat tenun bukan mesin (ATBM) tersaingi oleh alat tenun mesin (ATM) sehingga para pengrajin tenun kain yang menggunakan alat tenun bukan mesin (ATBM) mulai berhenti berproduksi keputusan itu diambil karena proses produksi atau kinerja alat tenun bukan mesin (ATBM) secara teknis kalah dengan alat tenun mesin (ATM) dengan kemampuan yang sudah lebih canggih, modern, efektif, efisien serta lebih ekonomis.

\section{Apakah Terdapat Pengaruh Perubahan Orientasi Produksi Alat Tenun Bukan Mesin (ATBM) dari Tenun Kain Kemjadi Tenun Keset Terhadap Peningkatan Pendapatan Pengrajin}

Untuk tetap mempertahankan pendapatan pengrajin dalam memenuhi kebutuhan hidup sehari-hari setelah sempat terpuruk dalam hal perekonomian, para pengrajin mulai menginovasi alat tenun bukan mesin (ATBM) yang mereka miliki yang pada awalnya alat tenun bukan mesin (ATBM) tersebut memproduksi tenun kain sekarang memproduksi tenun keset sebagai upaya untuk meningkatkan pendapatan pengrajin. Hal ini dapat dilihat pada tabel 6 di bawah ini.

Berdasarkan data di atas dapat diketahui bahwa pendapatan pengrajin sebagian kecil (6\%) antara Rp. 1.000.000 2.000.000 dikarenakan hasil produksi yang dihasilkan sedikit, serta menurut pernyataan responden keahlian ataupun pekerjaan menenun keset belum begitu lama, hampir seluruhnya (86\%) antara Rp. 2.000.000 3.000 .000 karena menurut pernyataan pengrajin merka sudah cukup lama dibidang pertenunan, dan sebagian kecil $(7 \%)$ anatara 3.000.000 - 4.000.000 ini dikarenakan jumlah produksi tenun yang dihasilkan oleh para pengrajin lebih banyak. 
Tabel 6. Pendapat Responden Berdasarkan Penghasilan Tenun Keset (ATBM)

\begin{tabular}{cccc}
\hline No. & Option & F & \% \\
\hline 1. & Rp. $1.000 .000-2.000 .000$ & 4 & 6 \\
2. & Rp. $2.000 .000-3.000 .000$ & 57 & 86 \\
3. & Rp. $3.000 .000-4.000 .000$ & 5 & 7 \\
4. & Rp. 4.000 .000 & - & - \\
\hline & Jumlah & $\mathbf{6 6}$ & $\mathbf{1 0 0}$ \\
\hline & Sumber: Hasil Penelitian Penulis Tahun 2019
\end{tabular}

\section{SIMPULAN}

Berdasarkan hasil penelitian yang telah dilakukan dan hasil analisis mengenai "Perubahan Orientasi Produksi Alat Tenun Bukan Mesin (ATBM) dari Tenun Kain Menjadi Tenun Keset (Upaya Peningkatan Pendapatan Pengrajin di Kecamatan Ibun Kabupaten Bandung)". Maka dari hasil penelitian ini diperoleh kesimpulan sebagai berikut:

1. Kecamatan Ibun secara topografi dan iklim memang cocoknya untuk menjadi daerah pertanian, tetapi karena kultur masyarakatnya yang berada dilingkungan Majalaya dan sekitarnya adalah wilayah yang terkenal sebagai masyarakat indsutri, maka meskipun Kecamatan Ibun cocok untuk wilayah pertanian tetapi penduduknya lebih banyak dibidang perindustrian baik industri kecil maupun industri besar.

2. Keberadaan industri tenun tradisional di Kecamatan Ibun merupakan kehadiran industri tenun tradisional yang masih menggunakan alat tenun bukan mesin (ATBM). Alat tersebut terbuat dari kayu dan dioperasikan oleh tenaga manusia. Keberadaan industri tenun tradisional masih bertahan hingga saat ini meskipun produksi yang dihasilkan oleh alat tenun bukan mesin (ATBM) pada saat ini bukan lagi tenun kain tetapi tenun keset. Jadi, pada intinya keberadaan industri tenun tradisional yang menggunakan alat tenun bukan mesin (ATBM) masih bertahan pada era modern saat ini hanya sudah tidak sebanyak dahulu ketika masih menjadi pusat industri tradisional di wilayah Majalaya-Ibun.

\section{REKOMENDASI}

Berdasarkan kesimpulan di atas maka penulis memberikan saran untuk perkembangan industri kecil yang ada di Kecamatan Ibun sebagai berikut:

1. Bagi pemerintah daerah diharapkan dapat memberikan dorongan, bimbingan, pelatihan dan bantuan secara berkesinambungan yang menaungi kelompok usaha kecil dan menengah yang ada di Kecamatan Ibun baik itu bantuan modal atau fasilitas produksi yang dapat mempermudah para pelaku industri.

2. Bagi para pelaku industri lebih mengembangkan lagi usaha yang sudah dimiliki supaya dapat menyerap tenaga kerja lebih banyak dan membantu meningkakan perekonomian masyarakat sekitar.

3. Bagi para pengrajin atau pegawai diharapkan mempunyai keterampilan yang lebih pareatif dalam membuat tenun keset supaya meningkatkan kualitas produksi.

4. Bagi peneliti selanjutnya hasil penelitian ini dapat menjadi bahan referensi dan tidak menutup kemungkinan karya tulis ilmiah ini terdapat kekurangan-kekurangan. Diharapkan penelitian selanjutnya mampu memberikan implikasi yang dibutuhkan oleh para penenun agar penelitian tidak sekedar penelitian, tetapi penelitian yang mampu mengubah industri tenun tradisional agar dapat berkembang pada era modern.

\section{DAFTAR PUSTAKA}

Aan, Komariah dan Djaman, Satori, 2012, Metodologi Penelitian Kualitatif, Bandung: Alfabeta

Arikunto, Sumarsini, 1997, Proses Penelitian Suatu Praktik, Jakarta: PT. Rineka Cipta 
Hardjono, 1990 dan Pleyte, 1912 dalam Keppy, 2001.

IKM TPT Majalaya, Indusri Kecil Menengah Tekstil dan Produk Tekstil Majalaya

Surakhmad, Winarno, 1980, Pengantar Penelitian Ilmiah, Purworejo: Tarsito

Sukmadinata, 2012, Metode Penelitian Pendidikan, Bandung: Pt. Remaja Rosdakarya
Sumaatmadja, Nursed, 1988, Studi Geografi, Bandung: Alumni

Suryatna, Rafi'i, 1995, Meteorologi dan Klimatologi, Bandung: Angkasa

Tika, Pabundu, 2005, Merode Penelitian Geografi, Jakarta: Bumi Kasara 